\title{
SISTEM AKUNTANSI \\ INTERNAL CONTROL ATAS PIUTANG FPD (1-6) \\ (STUDI KASUS PT. COLUMBUS MULTI SARANA) CABANG CIREBON
}

\author{
Suwandi $^{1}$,Turini ${ }^{2}$, Lena Magdalena ${ }^{3}$ \\ Universitas Catur Insan Cendekia ${ }^{1}$ \\ Universitas Catur Insan Cendekia ${ }^{2}$ \\ Universitas Catur Insan Cendekia ${ }^{3}$ \\ suwandi@cic.ac.id, turini@cic.ac.id, lena.magdalena@cic.ac.id
}

\begin{abstract}
PT.Columbus Multi Sarana is a multinational company engaged in the financing of electronic and furniture products. In terms of managing consumer receivables, PT.Columbus Multi Sarana carries out strict internal control by empowering competent employees in their respective fields. The purpose of this study was to analyze the internal control accounting system for accounts receivable. The receivables that the author discusses specifically for installments 1 to 6, better known as FPD 1-6 (First Payment Default). The author uses a descriptive research method, which is a method that describes the characteristics of the research population or the phenomenon under study, where the main focus is the object under study. The results of the research conducted by the author is where the internal control of receivables (especially FPD 1-6) at PT.Columbus Multi Sarana Cirebon Branch has been carried out since an early age, so that the consumer payment pattern is formed from the initial installment (FPD 16). As a result, consumers are accustomed to making credit installment payments according to the due date and on time. This tight control of receivables from the outset can result in the risk of bad credit being minimized.
\end{abstract}

Keywords: System, Accounting, Internal Control, Accounts Receivable, Credit Risk

\section{Pendahuluan}

Objek penelitian yang penulis lakukan adalah PT. Columbus Multi Sarana Cabang Cirebon, perusahaan ini bergerak di bidang kredit peralatan rumah tangga (elektronik, furniture, dan lain-lain). Jangka waktu kredit (tenor) yang diberikan adalah mulai dari 12, 15, 18 sampai maksimal 24 bulan. Semakin lama tenor yang diberikan, maka risiko kredit macet ke depannya juga semakin besar. Masalah yang ditemukan penulis saat melakukan penelitian ini adalah adanya konsumen atau nasabah yang belum melakukan pembayaran atau cicilan di angsuran awal (FPD 1-6), sehingga sangat berisiko menjadi kredit macet. Tujuan penelitian ini adalah untuk mengetahui penanganan piutang pada objek penelitian, khususnya angsuran ke-1 sampai dengan angsuran ke-6. Hasil dari penelitian ini adalah dengan dilakukannya penanganan piutang secara ketat sejak awal, dapat meminimalisasi tingkat tunggakan atau kredit macet, sehingga kinerja perusahaan di bidang penagihan dapat meningkat. Jika kinerja meningkat, secara otomatis kinerja keuangannya juga akan menunjukkan tingkat profitabilias yang tinggi.

Perusahaan sejenis di bidang kredit (di Kota Cirebon) ini cukup banyak. Hal ini membuat PT. Columbus Mutlisarana harus bekerja extra untuk mendapatkan calon nasabah. Mendapatkan nasabah / konsumen yang ingin melakukan kredit harus dilakukan secara ekstra hati-hati, mengingat risiko kredit macet cukup tinggi. Dengan demikian harus ada kerjasama yang solid antara tim marketing (tenaga penjual) dan tim collection (tenaga penagih) di lapangan. Karena jika mereka hanya memikirkan bidangnya saja otomatis visi dan misi perusahaan tidak akan tercapai. Perusahaan memiliki visi yaitu mencapai target penjualan dan penagihan setiap bulannya sesuai target yang telah ditetapkan. Target penjualan minimal tercapai $100 \%$, target penagihan tertagih minimal 95\%. Dengan adanya target yang harus dicapai setiap 
bulannya tersebut, pimpinan PT. Columbus Multisarana Cabang Cirebon (Direktur Operasional) benarbenar harus bekerja dengan penuh rasa tanggung jawab.

\section{Tinjauan pustaka dan pengembangan hipotesis}

Penelitian yang berjudul tentang pengendalian piutang sudah banyak dilakukan oleh penulis-penulis sebelumnya. Namun penelitian yang penulis lakukan saat ini terdapat keterbaruan atau perbedaan. Perbedaannya adalah terletak pada keterlibatan penulis melakukan penelitian ke lapangan, baik di bidang penjualan ataupun di bidang penagihan. Di bidang penjualan, penulis melakukan penelitian dengan 2 cara, yaitu melakukan 'direct selling' bersama sales force, dan penjualan di showroom bersama pramuniaga. Sementara itu di bidang penagihan, penulis melakukan penagihan secara langsung ke rumah konsumen dengan didampingi oleh karyawan perusahaan. Dengan keterlibatan penulis di bidang penjualan dan penagihan menjadikan penulis mendapatkan pengalaman baru di dunia kredit.

Tugas berat yang dipikul oleh Direktur Operasional adalah bagaimana setiap bulannya dapat mencapai target penjualan (100\%), dan target penagihan piutang 95\%). Target tersebut adalah target minimal yang harus dicapai setiap bulannya. Dilematis bagi seorang pimpinan PT. Columbus Multi Sarana Cabang Cirebon aladah ketika beliau mengejar target di bidang penjualan, akan tetapi risiko yang akan dihadapi adalah kemungkinan kredit macet. Jika penjualan kredit tidak mencapai target, otomatis laporan keuangan akan mengalami kerugian. Begitupun hal yang sama, jika penagihan piutang tidak dapat tercapai sesuai terget, maka cashflow perusahaan akan menurun.

Dari pengamatan di atas penulis mendapatkan sebuah ilmu dari seorang pimpinan di perusahaan kredit yaitu harus dapat membuat "balance" di bidang penjualan dan di bidang penagihan piutang. Hal ini sangat berbeda dengan perusahaan dagang yang melakukan penjualan secara tunai. Perusahaan dagang yang melakukan penjualan secara tunai akan lebih mudah mencari calon kosumen, karen jika sudah menerima [embayaran tunai tidak perlu melakukan penagihan angsuran di bulan-bulan berikutnya.

Peran Direktur Operasional di PT. Columbus Multi Sarana Cabang Cirebon dalam mengelola piutang nasabah begitu vital. Karena jika tidak memiliki pengalaman yang mumpuni tentunya akan terjadinya tingkat tunggakan yang cukup tinggi. Akibat tidak tertagihnya nasabah yang tidak melakukan pembayaran (wan prestasi). Penanganan piutang di perusahaan kredit adalah bukan merupakan hal yang mudah, mengingat karekter konsumen yang kadang berbeda ketika dilakukan proses awal 'survey' dan dilakukan 'penagihan'. Saat awal dilakukannya proses survey, calon nasabah akan berusaha bersikap baik agar permohonan kreditnya disetujui. Namun sebaliknya, bagi nasabah yang karekternya kurang baik, akan menunjukkan karakter aslinya ketika dilakukan penagihan.

Dari perbedaan karakter masing-masing nasabah inilah, seorang surveyor harus melakukan analisa calon konsumen dengan menggunakan analisa 5-C. Analisa 5-C yaitu terdiri dari (1)Caracter, yaitu seorang surveyor harus dapat memahami karekter calon nasabah, harus dapat membedakan calon nasabah yang baik, atau pura-pura baik. Pengalaman atau jam terbang seorang surveyor sangat dibutuhkan dalam menganalisa caracter calon nasabah. (2)Capacity, atau kapasitas calon nasabah. Kapasitas calon nasabah dapat dilihat dari penghasilan calon nasabah. Seorang surveyor harus dapat menganalisa kapsitas calon nasabah selama masa angsuran (misal tenor 24 bulan). Jika ada calon nasabah yang melakukan proses kredit selama 24 bulan, maka seorang surveyor harus dapat menganalisa bahwa calon nasabah tersebut secara kapasitas dapat membayar cicilan atau angsuran selama 24 bulan (lunas). (3)Capital, adalah tingkat modal atau aset yang dimiliki calon nasabah. Saat melakukan survey ke rumah calon nasabah, seorang surveyor harus dapat menganalisa capital atau aset yang ada di rumah calon nasabah tersebut. Seperti kepemilikan rumah, kendaraan pribadi, dan aset lainnya yang ada di dalam rumah calon nasabah. Sederhananya adalah, seorang survey harus dapat menghitung jika sewaktu-waktu nasabah tersebut menunggak, setidaknya masih memiliki aset yang likuiditas. (4)Condition atau kondisi adalah keadaan calon nasabah saat disurvey. Kondisi dapat dilihat dari pekerjaan calon nasabah, seorang surveyor harus mendapatkan informasi yang tepat apakah calon nasabah masih bekerja dan kondisi pekerjaannya tidak rawan di PHK atau bangkrut. Jika calon nasabah bekerja di perusahaan multinasional atau di BUMN tentunya kondisi ini relatif cukup baik, jika dibandingkan dengan pekerjaan calon nasabah adalah serabutan. (5)Collateral atau jaminan, yaitu sorang surveyor harus dapat menganalalisa jaminan yang diberikan oleh calon nasabah. Jaminan yang diberikan calon nasabah harus di atas nilai pengajuan kredit calon nasabah. Hal ini adalah sebagai langkah akhir jika sewaktu-waktu nasabah wanprestasi. Nilai jaminan atau agunan juga harus di cek, apakah setiap tahun nilainya akan menurun atau sebaliknya. Karena pada dasarnya jaminan atau agunan 


\section{Seminar Ilmiah Sistem Informasi Manajemen dan Akuntansi (SISIMA) 2021}

yang diberikan oleh calon nasabah secara psikologis akan membuat calon nasabah akan serius dalam membayar kewajiban kredit.

Beberapa penelitian sebelumnya yang bertema pengendalian piutang antara lain: (1) Analisis Sistem Pengendalian Piutang Terhadap Piutang Tak Tertagih Pada Koperasi Swamitra Wahana Putra Bengkalis, M. Khairul Amri dan Decky Hendarsyah dalam Jurnal Akuntansi Syariah (JAS), Vol.1 No.1 tahun 2017 hasilnya adalah melakukan analisa permohonan pinjaman, melakukan kunjungan ke lokasi tempat usaha nasabah atau konsumen, menganalisa jaminan yang diberikan, analisa kondii kediaman atau rumah calon nasabahj, serta BI Checking.

(2)Analisis Sistem Pengendalian Internal Piutang Usaha pada PT. Bank Sulutogo KCP Ranotana, Andi Maujung Tjodi, David P. E. Saerang dalam Jurnal EMBA Vol. 5 No. 2 tahun 2017, hasil yang diperoleh dari penelitian ini adalah internal control yang dilakukan dalam penanganan piutang sudah dapat dijalankan dengan baik.

(3) Sistem Informasi Akuntansi Piutang Nasabah Menggunakan Metode Cadangan (Allowance), Ceriawati Gulo, Nita Syahputri, Khairani Puspita (2018), Proceeding Seminar Nasional Sistem Informasi dan Teknologi Informasi (SENSITEK), hasil dari penilitan ini adalah munculnya saldo cadangan kerugian piutang di laporan keuangan, yang disajikan dengan angka minus di bawah piutang nasabah. Sehingga perusahaan dapat menggunakan sistem ini untuk menghasilkan laporan mengenai piutang nasabah yang dapat menentukan jumlah piutang nasabah.

(4) Analisis Perlakuan Akuntansu Piutang Pada UD. Rokan Deli Utama Pekanbaru, Suharti \& Maria (2018), Hasil penelitian menunjukkan pencatatan piutang pada perusahaan ini belum sesuai dengan PSAK.

(5) Aanalisis Piutang Tak Tertagih Dan Dampaknya Terhadap Laporan Keuangan Pada PT Bank Rakyat Indonesia (Persero) TBK Cabang Mano, Grace Gloria Tampi, Inggriani Elim, Meily Y.B Kalalo (2019), hasil dari penelitian ini adalah PT Bank Rakyat Indonesia (Persero) Tbk Cabang Manado menggunakan perhitungan estimasi pembentukan PPAP atau metode cadangan kerugian piutang dengan memperkirakan piutang tak tertagih dari semua pemberian kredit yang beredar untuk menentukan besarnya kerugian piutang.

(6) Analisis Pengaruh Piutang Dan Penjualan Kredit Terhadap Profitabilitas Perusahaan Tahun 20162018 (Studi Kasus CV Davin Jaya Karimun), Yusmalina, Sinta Novita Sari \& Fauzan Haqiqi. (2020), Jurnal Cafetaria Vol. 1, No.2, hasil penelilitan ini yaitu Pengaruh variabel Piutang (X1) dan Penjualan Kredit (X2) terhadap profitabilitas (Y), Berdasarkan tabel diperoleh nilai $\mathrm{F}$ hitung 258951,568 dengan nilai sig sebesar 0,000. Hal ini menunjukkan nilai sig lebih kecil dari 0,05. Dengan demikian H0 ditolak dan Ha diterima. Dengan demikian dapat diartikan bahwa terdapat pengaruh signifikan terhadap profitabilitas, adanya piutang dan penjualan kredit ini.

(7) Analisis Efektivitas Sistem Prosedur Piutang pada PUD BPR Bank Pasar Pontianak, Elisabet Sherlya (2018), Jurnal KIAFE Vol.7, No.2, Hasil dari penelitian ini adalah sistem prosedur piutang pada PUD BPR Bank Pasar Pontianak yang berjalan sudah dapat dilakukan dengan baik dan efektif.

(8)Analisis Piutang Tak Tertagih pada PT Astra International Tbk, Aris Munandar, Nurul Huda \& Muhajirin (2018), Jurnal Manajemen dan Keuangan (JMK), Vol.7, No.2, penelitian ini menghasilkan laporan yaitu piutang tak tertagih PT Astra Internasional Tbk rata-rata selama 5 tahun terakhir sebesar $3,36 \%$ yang berarti termasuk tinggi tunggakan tersebut.

(9) Analisis Manajemen Piutang Dalam Meningkatkan Volume Penjualan (Studi pada PT Varia Usaha Beton, Waru-Sidoarjo Periode 2013), Yustin Hanifah (2014), Jurnal Administrasi dan Bisnis, Vo. 16. No.1, Hasil penelitian menunjukkan bahwa penyebab salah satu hal yang menyebabkan penjualan tidak dapat mencapai target adalah adanya kebijakan penjualan kredit yang masih belum berjalan dengan baik, serta penyebab semakin lamanya perputaran piutang yaitu karena kinerja bagian penagihan yang kurang optimal.

(10) Analisis Pengendalian Intern Piutang Usaha Pada PT. Adira Finance Cabang Manado, Nabila Habibie (2013), Jurnal EMBA Vol.1, No.3, hasil penelitian menyebutkan bahwa secara keseluruhan pengendalian atas piutang usaha sudah berjalan secara efektif, dimana manajemen perusahaan sudah menerapkan konsep dan prinsip-prinsip pengendalian intern seuai SOP perusahaan. 
First Payment Default (FPD) artinya istilah dalam dunia pembiayaan yang merupakan indikator awal perusahaan untuk menganalisa baik atau buruknya seorang konsumen atau nasabah dalam melakukan pembayaran. FPD ini biasanya dinilai pada 6 bulan cicilan pertama setelah konsumen atau nasabah tersebut resmi menjadi konumen atau nasabah perusahaan. Jika dalam periode 6 cicilan peulan rtama seorang konsumen sudah menunggak dalam pembayaran cicilan, maka besar kemungkinan ke depannya nasabah tersebut akan wanprestasi.

Permasalahan yang akan penulis bahas dalam penelitian ini adalah efektifnya pengendalian internal atas piutang konsumen (khususnya FPD 1-6) pada PT.Columbus Multi Sarana Cabang Cirebon.

\section{Metode penelitian}

Penulis menggunakan metode penelitian deskriptif, yaitu merupakan suatu metode yang menggambarkan karakteristik populasi penelitian atau fenomena yang diteliti, yaitu yang menjadi fokus utama adalah objek yang diteliti.

\subsection{Teknik Pengumpulan Data}

Berikut ini beberapa metode pengumpulan data yang digunakan dalam penelitian:

\subsection{Wawancara}

Proses Wawancara yang penulis lakukan yaitu melalui tanya jawab secara langsung antara peneliti dengan narasumber yaitu karyawan departemen piutang PT. Columbus Multi Sarana Cabang Cirebon. Proses wawancara juga dapat pula dilakukan melalui media-media tertentu, misalnya telepon, WA ataupun Videocall.

\subsubsection{Observasi}

Observasi yang dilakukan dilakukan dalam rangka pengumpulan data adalah dengan melibatkan berbagai faktor dalam pelaksanaannya.

\subsubsection{Studi Perpustakaan}

Informasi studi kepustakaan dapat diperoleh dari buku-buku ilmiah, laporan penelitian, karangankarangan ilmiah, tesis dan disertasi, peraturan-peraturan, dan sumber-sumber tertulis baik tercetak maupun elektronik lain.

\subsection{Objek Penelitian}

Objek penelitian dilaksanakan di PT. Columbus Multi Sarana Cabang Cirebon, Jalan Siliwangi Cirebon.

\section{Hasil dan pembahasan}

\section{Struktur Organisasi PT. Columbus Multi Sarana Cabang Cirebon}




\section{Seminar Ilmiah Sistem Informasi Manajemen dan Akuntansi (SISIMA) 2021}

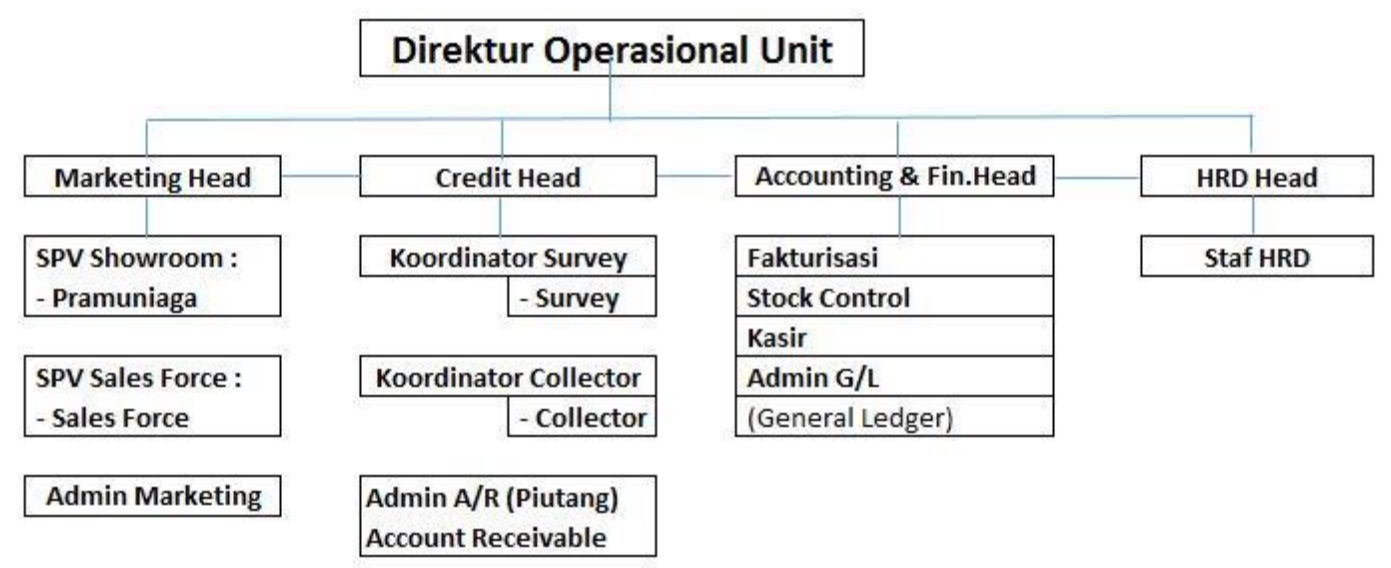

Gambar.1 Struktur Organisasi PT. Columbus Multi Sarana - Cabang Cirebon

Gambar-1 adalah struktur organisasi PT. Columbus Multi Sarana Cabang Cirebon, berikut ini adalah sekilas tentang tugas dan tanggung jawab sesuai dengan jabatannya :

1. Direktur Operasional

Seorang direktur operasional mempuyai tugas dan tanggung jawab di 4 bidang yaitu : bidang penjualan, penagihan, akuntansi dan keuangan, dan bidang sumber daya manusia (SDM).

Di bidang penjualan tugas dan tanggung jawab seorang direktur operasional adalah bagaimana setiap bulannya perusahaan dapat mencapai target penjualan yang telah ditetapkan. Di penagihan, seorang direktur operasional memiliki tugas tan tanggung jawab dalam hal pengelolaan piutang nasabah, dimana target minimal 95\% harus tertagih setiap bulannya (dari total piutang jatuh tempo per bulan). Di bidang akuntansi dan keuangan, tugasnya adalah memastikan cashflow perusahaan dapat berjalan dengan baik, dapat membuat laporan keuangan secara tepat wakru. Sementara itu tugasnya di bidang SDM adalah harus dapat memenuhi targat man power (khususnya SDM) di bidang penjualan. Pimpinan juga harus dapat membuat suasana kerja yang kondusif dan mencipatkan tim yang dapat bekerjasama dengan solid.

2. Marketing Head

Marketing Head memiliki tugas dan tanggung jawab harus dapat mencapai omset penjualan setiap bulannya sesuai target yang diberikan yang diterimanya dari seorang Direktur Operasional. Jika secara 3 bulan berturut-turut seorang marketing head tidak dapat melakukan pencapaian target di bidang penjualan, maka seorang Direktur Operasional berhak untuk melakukan evaluasi atau pergantian jabatan marketing head tersebut, dengan berbagai macam pertimbangan.

3. Credit Head

Credit Head atau kepala kredit bertugas dan bertanggung jawab atas bidang penagihan dan bidang kredit. Di bidang kredit harus dapat menciptakan penjualan kredit yang berkualitas, sehingga dapat meminimalisasi terjadinya tunggakan. Di bidang penagihan harus dapat mencapai target penagihan piutang nasabah minimal 95\% dari total posisi piutang jatuh tempo per bulan.

4. Accounting \& Finance Head 
Tugas dari accounting \& finance head di PT. Columbus Multi Sarana Cabang Cirebon adalah sebagai berikut :

-memastikan cash flow perusahaan dapat berjalan dengan baik

-melakukan penghematan biaya di segala bidang

-memastikan pembayaran uang makan sales force dapat dibayarkan tepat waktu

-membuat laporan keuangan setiap bulan

-memberikan data yang dibutuhkan oleh manajemen

5. HRD Head

Tugas dari HRD Head adalah melakukan perekrutan calon karyawan, interview dan psikotest calon karyawan, mendapatkan calon karyawan yang 'the right man on the right place', meretensi karyawan.

6. Supervisor / Korrdinator

Bertanggung jawab sesuai bidangnya masing-masing, dan selalu melakukan komunikasi dan koordinasi dengan atasan langsung.

7. Administrasi / Staff

Melakukan tugas dan tanggung jawabnya sesuai fungsi administrasinya masing-masing. Membuat laporan harian yang dibutuhkan oleh masing-masing atasannya.

Dari struktur organisasi tersbut di atas dapat terlihat tugas dan tanggung jawab yang diberikan sesuai jabatannya. Adanya proses evaluasi yang tegas jika masing-masing bagian atau jabatan tidak dapat menjalankan tugasnya dengan baik dan penuh rasa tanggung jawab.

\section{Berikut ini adalah Siklus Bisnis pada Objek penelitian :}

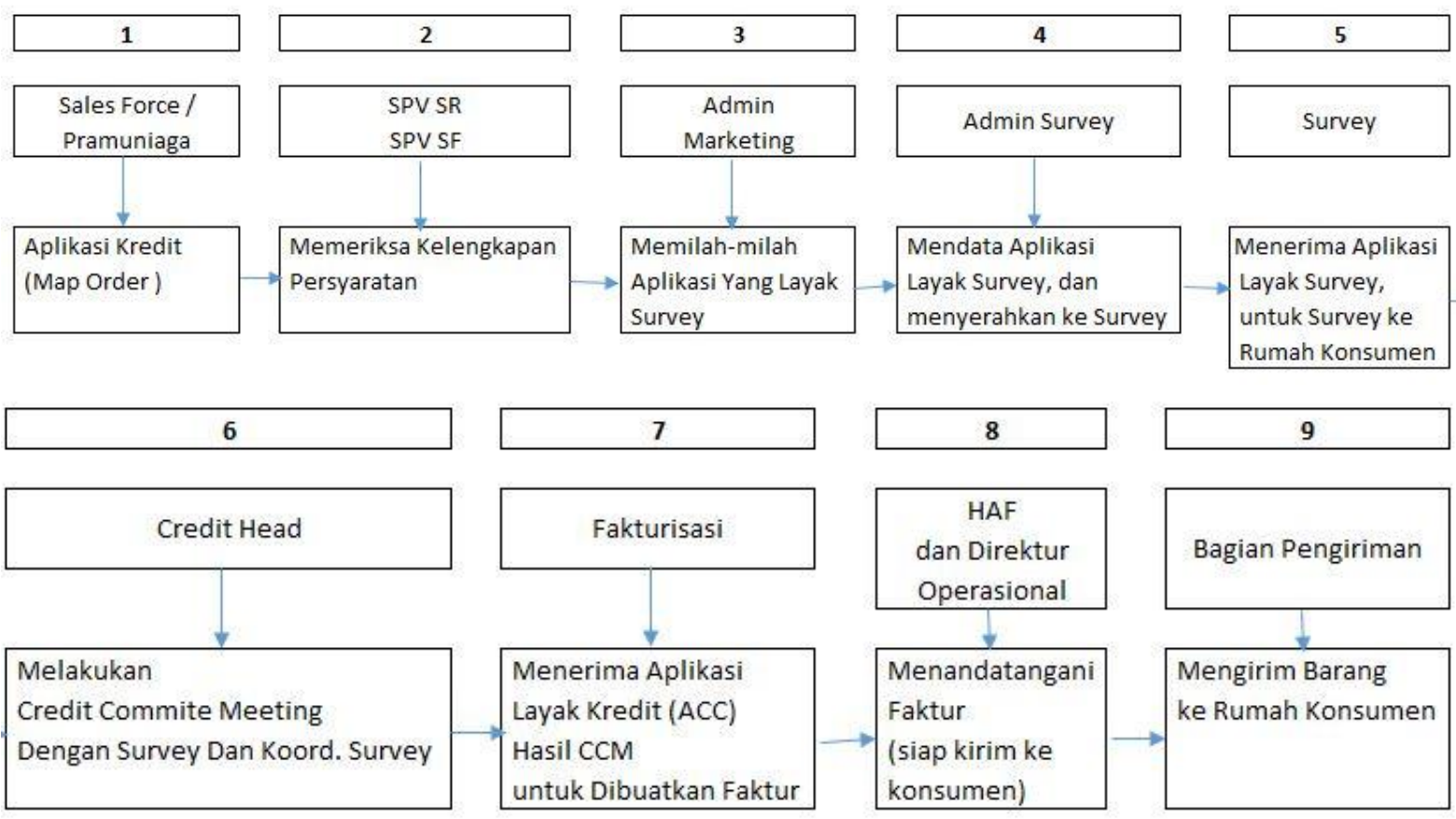

\section{Gambar-2 Siklus Bisnis PT. Columbus Multi Sarana - Cabang Cirebon}

Keterangan Gambar-1 :

Piutang yang terbentuk adalah akibat adanya penjualan yang dilakukan secara kredit (pembayaran secara cicilan per bulan) pada PT.Columbus Multi Sarana Cabang Cirebon. Adapun tahapan terbentuknya piutang / tagihan adalah sebagai berikut: 


\section{Seminar Ilmiah Sistem Informasi Manajemen dan Akuntansi (SISIMA) 2021

1. Tim marketing atau tenaga penjual di perusahaan ini ada 2 jenis, yaitu Sales force dan pramuniaga. Perbedaan keduanya adalah sebagai berikut, sales force mendapatkan calon konsumen melalui penawaran secara 'direct selling', sedangkan pramuniaga mempeoleh konsumen melalui kunjungan atau konsumen yang datang ke showroom atau toko.

Tahap awal terbentuknya piutang pada perusahaan ini yaitu Tenaga Penjual menerima berkas permohonan pinjaman dari calon nasabah. Tenaga penjual mendapatkan aplikasi pinjaman berdasarkan kunjungan prospek atau mendapatkan aplikasi pinjaman konsumen dari prospek yang datang ke showroom. Selanjutnya aplikasi tersebut diserahkan kepada Supervisor untuk dilakukan proses pemeriksaan persyaratan kredit.

2. Aplikasi pinjaman yang diterima oleh supervisor akan diperiksa kelayakannya. Setelah persyaratannya lengkap, supervisor mengirimkan aplikasi pinjaman ke bagian administrasi penjualan.

3. Langkah selanjutnya adalah bagian Administrasi Penjualan mencatat (mengulang) aplikasi pinjaman yang diterima dari supervisor dan memverifikasi persyaratan dan file lainnya. Setelah itu, semua file (aplikasi pinjaman) dikirim ke bagian admin survei.

4. Selanjutnya, bagian Administrasi Survey melakukan pencatatan data-data map order yang diterima dari admin penjualan ke dalam Laporan Harian Map Order. Oleh Admin Survey, aplikasi ini dipilah-pilah untuk menentukan mana yang layak survey dan yang tidak layak survey, aplikasi permohonan kredit yang layak dilakukan proses survey diserahkan ke bagian survey (analis kredit) untuk selanjutnya dilakukan tahapan survey ke rumah calon konsumen.

5. Setelah menerima berkas yang layak survey (dari bagian admin survey), surveyor kemudian menjalankan tugasnya sebagai seorang surveyor dengan melakukan kunjungan ke rumah atau tempat kerja calon konsumen (pemohon kredit).

6. Selambat-lambatnya, 1 hari setelah dilakukan proses survey ke rumah calon konsumen, hasilnya dibuat laporan tertulis dalam bentuk "laporan hasil survey" atau LHS. Laporan hasil survey tersebut selanjutnya oleh surveyor di ajukan ke Credit Commite Meeting (CCM) untuk menentukan apakah konsumen tersebut layak diberikan kredit atau tidak layak diberikan kredit. Tahap CCM ini dihadiri oleh Koordinator Survey, Credit Head dan juga Branch Manager (Direktur Operasional).

7. Hasil CCM yang disetujui permohonan kreditnya ditandatangani oleh peserta meeting CCM, selanjutnya diserahkan ke bagian accounting (fakturisasi) untuk dibuatkan faktur penjualan kredit. Sedangkan aplikasi yang permohonannya ditolak atau tidak disetujui permohonan kreditnya di arsip oleh bagian administrasi survey.

8. Setelah dibuat faktur penjualan kredit, bagian fakturisasi melakukan proses validasi faktur dengan menyerahkan faktur tersebut untuk divalidasi atau di tanda tangan oleh oleh Chief Accounting dan Branch Manager.

9. Faktur penjualan kredit yang sudah di tandatangani diserahkan ke bagian gudang (pengiriman barang) untuk dilakukan pengiriman barang ke rumah konsumen.

10. Setelah barang diterima konsumen, maka ditahap inilah terciptanya "piutang" atas penjualan kredit.

Internal Control atas Piutang pada PT. Columbus Multi Sarana Cabang Cirebon 
1. Jika barang/produk yang dipesan konsumen dikirimkan oleh bagian pengiriman dan barang sudah diterima oleh konsumen, maka konsumen harus menandatangani faktur penjualan sebagai bukti bahwa barang telah diterima oleh konsumen. Konsumen membayar jumlah dalam bentuk deposit atau biaya untuk pembayaran angsuran pertama, dan departemen pengiriman mengeluarkan tanda terima untuk menerima uang. Departemen pengiriman kemudian mengirimkan semua file dan tanda terima pembayaran ( 2 eksemplar) ke petugas (buku besar) dan administrator AR (penangan klaim). Petugas memposting pembayaran IT atau pembayaran angsuran pertama untuk konsumen baru dalam program akuntansi yang disebut program IT terintegrasi. Sementara itu, admin A/R akan melakukan posting manual ke kartu A/R (kartu debitur) sesuai dengan nomor invoice dan nama konsumen. Langkah selanjutnya dalam mengelola piutang adalah membandingkan piutang yang dicatat oleh petugas menggunakan komputer dengan kartu piutang yang dicatat oleh bagian piutang (accounts receivable department).H+1 setelah barang dikirim ke rumah konsumen, Bagian Admin Survey melakukan verifikasi via telepon kepada konsumen yang telah menerima barang. Hal ini dilakukan untuk memastikan bahwa barang yang dipesan secara kredit oleh konsumen diterima dengan baik, oleh konsumen (sesuai data yang ada, sesuai KTP Pemohon).

2. Bulan berikutnya, staf accounting mengeluarkan Daftar nama-nama konsumen yang jatuh tempo khusus pembayaran angsuran ke-1 sampai dengan angsuran ke-6 dan diserah ke Admin Survey.

3. Setiap hari dilakukan komunikasi dan koordinasi oleh admin survey dengan bagian survey (credit analis) tentang nama-nama konsumen angsuran ke-1 sampai dengan angsuran ke-6, belum melakukan pembayaran padahal sudah jatuh tempo.

4. Tahap berikutnya adalah dilakukananya tellecollection (menghubungi konsumen via telepon) oleh bagian admin survey, untuk memberitahu konsumen perihal jatuh tempo angsuran, dan memberikan petunjuk kepada konsumen agar melakukan pembayaran secara online / transfer ke rekening ataupun fasilitas yang telah disediakan.

5. Jika ada konsumen yang 3 kali janji akan melakukan pembayaran namun belum juga melakukan pembayaran, secara otomatis tim penagihan (collector) akan mendatangi rumah konsumen tersebut untuk segera melakulan pembayaran sesuai janji.

6. Salah satu keberhasilan penanganan piutang pada objek penelitian ini adalah keterlibatan Kepala Cabang (Direktur Operasional) dan Kepala Kredit dalam melakukan pengendalian piutang nasabah. Mereka secara rutin melakukan 'on the spot' ke rumah nasabah mengecek kondisi piutang nasabah yang sebenarnya terjadi di lapangan. Aktivitas ini dilakukan dalam rangka mengurangi tindakan kecurangan yang dilakukan oleh collector (bagian penagihan). 


\section{Seminar Ilmiah Sistem Informasi Manajemen dan Akuntansi (SISIMA) 2021}

\section{Kesimpulan}

1. Pengendalian Intern atau tindakan prefentif atas piutang yang dilakukan oleh PT. Columbus Multi Sarana Cabang Cirebon sudah dikelola dengan rapih. Piutang nasabah dapat dipantau setiap hari berdasarkan laporan posisi piutang jatuh tempo, khususnya piutang angsuran ke-1 sampai dengan angsuran ke-6. Dengan demikian setiap hari akan terpantau nama-nama konsumen (Angsuran 1 6) yang sudah jatuh tempo tetapi belum melakukan pembayaran. Pada saat briefing pagi, administrasi survey akan membacakan nama-nama konsumen yang belum melakukan pembayaran, dan colector akan memberikan jawaban perihal keterlambatan pembayaran konsumen tersebut.

2. Dalam menangani piutang konsumen (angsiran 1 - angsuran 6) memerlukan kerjasama dari seluruh karyawan yang terlibat di dalamnya. Saat ini, kerjasama tim berjalan dengan penuh rasa tanggung jawab, dimana komunikasi antar karyawan dalam hal pengendalian piutang konsumen sangat baik, khususnya dalam mengelola piutang yang nasabah yang akan ditagih. Solidnya tim penagihan ini membuat kinerja di bidang penagihan selalu mencapai target yang telah ditetapkan oleh perusahaan yaitu minimal $95 \%$ tertagih.

3. Tindakan prefentif dan kuratif atas atas piutang nasabah, khususnya angsuran First Payment Default (FPD) yang dilakukan oleh manajemen perusahaan dinilai cukup efektif, di mana konsumen dapat dipantau sejak dini pada angsuran ke-1 sampai dengan angsuran ke-6, sehingga dapat keseluruhan piutang yang jatuh tempo dapat tertagih sesuai deadline.

\section{Limitasi dan studi lanjutan Limitasi Penelitian}

Limitasi pada penelitian ini terletak pada fokus penelitian yaitu FPD 1-6, bukan seluruh piutang sampai dengan angsuran terakhir. Penulis meneliti FPD 1-6 dikarenakan ingin mengetahui tindakan prefentif dalam mengelola piutang untuk angsuran ke-1 sampai dengan angsuran ke-6. Karena jika konsumen sudah dipantau secara ketat piutangnya sejak dini (FPD 1-6), maka ke depannya akan lebih mudah dalam penanganan piutang.

\section{Studi Lanjutan}

Penelitian ini akan penulis lanjutkan dengan melakukan analisa piutang angsuran sampai dengan angsuran terakhir (lunas).

\section{Ucapan terima kasih}

Penulis ucapkan terima kasih kepada Bapak. Tanto (Selaku Branch Manager PT. Columbus Mutli Sarana) yang telah memberikan kesempatan kepada penulis untuk dapat melakukan penelitian di Perusahaan ini. Seluruh karyawan PT. Columbus Multi Sarana Cabang Cirebon yang telah memberikan informasi ketika penulis melakukan wawancara maupun membantu melakukan on the spot ke lapangan.

\section{REFERENSI}

Amri, M. K., \& Hendarsyah, D. (2017). Analisis Sistem Pengendalian PiutangTerhadap Piutang Tak Tertagih Pada Koperasi Swamitra Wahana Putra Bengkalis. JAS (Jurnal Akuntansi Syariah), 1(1), 187-206. https://doi.org/10.46367/jas.v1i1.105

Andi Maujung Tjodi, David P. E. Saerang (2017), Analisis Sistem Pengendalian Internal Piutang Usaha Pada PT. Bank Sulutgo KCP Ranotana. Jurnal EMBA: Jurnal Riset Ekonomi, Manajemen, Bisnis dan Akuntansi, Vol.5, No.2, Hal.857-866.

https://doi.org/10.35794/emba.v5i2.16002 
Aris Munandar, Nurul Huda \& Muhajirin (2018), Analisis Piutang Tak Tertagih pada PT Astra International Tbk, , Jurnal Manajemen dan Keuangan (JMK), Vol.7, No.2, Hal 184-191

Cahyarini M. (2018). Analisis Umur Piutang Untuk Meminimalisir Piutang Tak Tertagih pada PT Bisma Karang Pilang Surabaya. Jurnal Ilmiah Cendekia Akuntansi, 3(3), 49-57.

Ceriawati Gulo, Nita Syahputri, Khairani Puspita (2018), Sistem Informasi Akuntansi Piutang Nasabah Menggunakan Metode Cadangan (Allowance), Proceeding Seminar Nasional Sistem Informasi dan Teknologi Informasi (SENSITEK), Hal.710714,http://dx.doi.org/10.30700/pss.v1i1.249

Elisabet Sherlya (2018), Analisis Efektivitas Sistem Prosedur Piutang pada PUD BPR Bank Pasar Pontianak, Jurnal KIAFE Vol.7, No.2.

Grace Gloria Tampi, Inggriani Elim, Meily Y.B Kalalo (2019), ANALISIS PIUTANG TAK TERTAGIH DAN DAMPAKNYA TERHADAP LAPORAN KEUANGAN PADA PT BANK RAKYAT INDONESIA (PERSERO) TBK CABANG MANADO, Jurnal Riset Akuntansi, Vol. 14, No. 2, hal 230-236.

JK, Andryan Elfani, Yayuk Nurjanah, and Aang Munawar. "Peranan Sistem Informasi Akuntansi Piutang Terhadap Pengendalian Piutang (Studi Kasus Pada Pt. Arwinda Perwira Utama)." Jurnal Ilmiah Manajemen Kesatuan 7.1 (2019): 192-172.

Nabila Habibie (2013), Analisis Pengendalian Intern Piutang Usaha pada PT. Adira Finance Cabang Manado, Jurnal EMBA Vol.1, No.3

Novitasari, Maya, and Rizka Hardiyanti (2020). "Analisis Pengelolaan Piutang dan Potensi Piutang yang tidak tertagih Sebagai Tindak Lanjut Kebijakan Pembayaran Kredit Pada Bimbingan Belajar X di Madiun." Inventory: Jurnal Akuntansi 1, no. 2: 67-76.

SUHARTI, MARIA, (2018). ANALISIS PERLAKUAN AKUNTANSI PIUTANG PADA UD. ROKAN DELI UTAMA PEKANBARU. Bilancia : Jurnal Ilmiah Akuntansi, Vol. 2, No. 1, p. 107-121, ISSN 2685-5607.

Vitri Ratu Aulia \& Ririn Sari Dewi (2020), Analisis Penerapan Sistem Akuntansi Penjualan Kredit dan Penerimaan Kas dari Piutang dalam MendukungPengendalian Internal Perusahaan, Jurnal Penelitian Implementasi Akuntansi (JPIA), Vol.1, No.1

Wuisan, J. S. (2013). Analisis Efektifitas Pengendalian Intern Piutang Lease Pada PT. Finansia Multi Finance Tomohon. Jurnal EMBA: Jurnal RisetEkonomi, Manajemen, Bisnis dan Akuntansi, Vol 1(4).

Yusmalina, Sinta Novita Sari \& Fauzan Haqiqi (2020). ANALISIS PENGARUH PIUTANG DAN PENJUALAN KREDIT TERHADAP PROFITABILITAS PERUSAHAAN TAHUN 20162018 (STUDI KASUS CV DAVIN JAYA KARIMUN), Jurnal Cafetaria, Vol. 1, No.2, Hal. $13-22$.

Yustin Hanifah (2014), Analisis Manajemen Piutang Dalam Meningkatkan Volume Penjualan (Studi pada PT Varia Usaha Beton, Waru-Sidoarjo Periode 2013), , Jurnal Administrasi dan Bisnis, Vol. 16. No.1. 